DOI: https://doi.org/10.24127/ajpm.v9i2.2765

\title{
PENGARUH STRATEGI PEMBELAJARAN TIPE KOOPERATIF DAN KREATIVITAS SISWA TERHADAP HASIL BELAJAR MATEMATIKA
}

\author{
Budi Murtiyasa ${ }^{1}$, Widi Hayuningtyas ${ }^{2}$ \\ ${ }^{1,2}$ Pendidikan Matematika, Universitas Muhammadiyah Surakarta \\ E-mail: $\quad$ budi.murtiyasa@ums.ac.id ${ }^{1)}$ \\ widihayuningtyas@gmail.com ${ }^{2)}$
}

Received 19 April 2020; Received in revised form 21 June 2020; Accepted 26 June 2020

\begin{abstract}
Abstrak
Penelitian bertujuan untuk (1) menganalisis pengaruh strategi pembelajaran Student Teams Achievement Devision (STAD) dan Teams Games Tournament (TGT) terhadap hasil belajar matematika, (2) menganalisis pengaruh kreativitas siswa terhadap hasil belajar matematika, (3) mengetahui interaksi antara strategi pembelajaran dan kreativitas terhadap hasil belajar matematika. Jenis penelitian ini kuantitatif dengan desain penelitian eksperimen semu. Populasi penelitian ini seluruh siswa kelas VII SMP Negeri 3 Colomadu. Sampel diambil 2 kelas yang diberi perlakuan dengan strategi STAD dan strategi TGT. Teknik pengambilan sampel menggunakan Teknik cluster random sampling. Teknik pengumpulan data dengan metode tes, angket, dan dokumentasi. Teknik analisis data yang digunakan adalah analisis variansi dua jalur dengan sel tak sama. Berdasarkan hasil penelitian diperoleh: (1) Hasil belajar matematika siswa yang diberi pembelajaran menggunakan strategi pembelajaran STAD lebih baik dibandingkan dengan siswa yang diberi pembelajaran menggunakan strategi pembelajaran TGT. (2) Hasil belajar matematika siswa yang memiliki kreativitas tinggi lebih baik daripada siswa yang memiliki kreativitas rendah. (3) Tidak terdapat interaksi antara strategi pembelajaran dan kreativitas siswa terhadap hasil belajar matematika.
\end{abstract}

Kata kunci: hasil belajar matematika; kreativitas siswa; STAD; TGT.

\begin{abstract}
The goal of this research are 1) To analyze the learning strategy Student Teams Achievement Devision (STAD) and Teams Games Tournament (TGT), 2) To analyze the effect of student's creativity on learning outcome in mathematics, 3) To find out the interaction between learning strategy and student's creativity for mathematic learning outcome. This type of research is quantitative with quasi-experimental research designs. The population of this research is all students seventh grade classes of SMP N 3 Colomadu. Samples taken from two classes that treated with STAD strategy and TGT strategy. The sampling technique uses cluster random sampling. Data collection techniques with the method of tests, questionnaires, and documentation. The analysis technique used the analysis of variance of two paths with unequal cells. The research results obtained: (1) The student's mathematic learning outcome that use STAD learning strategy is better than student using TGT learning strategy. (2) The student's mathematic learning outcome that have high creativity is better than student that have low creativity. (3) There is no interaction between learning strategies and student's creativity with mathematics learning outcomes.
\end{abstract}

Keywords: mathematics learning outcome; student's creativity; STAD; TGT.

\section{PENDAHULUAN}

Matematika merupakan salah satu mata pelajaran yang wajib dikuasai siswa di semua jenjang pendidikan. Pembelajaran matematika yang berkualitas diharapkan mampu menjadikan siswa menguasai materi pembelajaran yang ditunjukkan dengan prestasi belajar matematika yang tinggi. Baik tidaknya hasil belajar yang diperoleh siswa merupakan indikator dari keberhasilan proses pembelajaran yang telah dilakukan. Secara umum hasil belajar matematika di Indonesia 
belum sesuai dengan harapan. Mengacu pada hasil studi Programme for International Student Assessment (PISA) tahun 2018 menunjukkan bahwa Indonesia berada di peringkat ke-72 dengan skor rata-rata matematika sebesar 379. Skor yang diperoleh tersebut tergolong rendah jika dibandingkan dengan rerata skor PISA negara-negara anggota Organization for Economic Cooperation and Development (OECD), di mana untuk matematika skor rata-rata sebesar 489 . Berdasarkan Rekapapitulasi Hasil Ujian Nasional tahun 2019 oleh Kemendikbud, prestasi siswa-siswa SMP Negeri 3 Colomadu masuk dalam katagori cukup. Diperoleh rata-rata hasil Ujian Nasional mata ujian matematika yaitu 62,98 dengan nilai terendah 27,5 dan nilai tertinggi 97,5. Hasil tersebut masih tergolong rendah jika dibandingkan dengan rata-rata mata ujian IPA dan Bahasa Indonesia yang dikatagorikan baik dengan perolehan rata-rata IPA yaitu 70,30 dan Bahasa Indonesia yaitu 81,92. Memperhatikan hasil ujian tersebut menunjukkan bahwa prestasi belajar matematika siswa-siswa SMP Negeri 3 Colomadu masih tergolong rendah. Perlu usaha untuk meningkatkan hasil belajar matematika.

$$
\text { Hasil belajar matematika }
$$

dipengaruhi oleh banyak faktor, baik faktor dari dalam siswa maupun dari luar siswa. Sesuai dengan hasil observasi dan wawancara dengan beberapa siswa dan guru SMP Negeri 3 Colomadu disebutkan ada beberapa faktor yang dapat mempengaruhi rendahnya hasil belajar matematika, yaitu: (1) alat peraga yang tersedia masih sedikit; (2) lembar kerja peserta didik (LKPD) kurang membantu siswa dalam memahami materi; (3) diskusi kelompok jarang dilakukan; (4) strategi pembelajaran yang digunakan guru kurang bervariasi; (5) kreativitas siswa dalam pembelajaran masih rendah, hal ini terlihat dari jawaban siswa saat mengerjakan soal matematika yang kurang bervariasi.

Faktor strategi pembelajaran yang digunakan guru tampaknya mempengaruhi aktifitas dan kreativitas siswa selama berlangsungnya proses pembelajaran. Strategi pembelajaran kooperatif dapat menjadi pilihan bagi guru untuk meningkatkan hasil belajar matematika siswa. Penelitian yang dilakukan Ling, Ghazali, \& Raman (2016) menunjukkan bahwa strategi pembelajaran kooperatif dapat meningkatkan hasil belajar matematika siswa, pemahaman, dan kepercayaan diri siswa. Sebagai contoh, strategi pembelajaran kooperatif tipe STAD telah memberikan dampak positif terhadap hasil belajar. Hal ini sesuai dengan penelitian yang dilakukan Rattanatumma (2016) menyimpulkan bahwa strategi STAD lebih efektif dalam meningkatkan hasil belajar matematika siswa dari pada strategi pembelajaran berbasis masalah. Penelitian Nurafifaeni, Triyanto, \& Chrisnawati (2018) menjelaskan bahwa strategi pembelajaran STAD dengan Mind Mapping memberikan hasil belajar matematika yang sama dengan pembelajaran langsung. Sementara itu, penelitian Alabekee, Samuel, \& Osaaat (2019) menyimpulkan bahwa ada perbedaan hasil belajar matematika siswa yang diajarkan menggunakan strategi JIGSAW II dan STAD.

Jahring, Armiana, \& Nasrum (2017) telah menerapkan strategi pembelajaran kooperatif tipe TGT. Strategi yang digunakan terbukti dapat meningkatkan keterlibatan siswa dalam proses pembelajaran. Hasil ini sesuai dengan penelitian Veloo, Md-Ali, \& Chairany (2016) yang menjukkan 
bahwa penerapan strategi TGT dapat mendorong guru maupun siswa untuk berinovatif dan kreatif serta meningkatkan pemahaman dan komunikasi siswa dalam pembelajaran matematika. Sementara itu Salam, Hossain, \& Rahman (2015) menyimpulkan bahwa penerapan strategi TGT dapat meningkatkan hasil belajar matematika. Penelitian yang dilakukan Puspitasari, Muliawanti, Gunawan, \& Sairan (2019) mengatakan bahwa penerapan strategi pembelajaran TGT berperan penting dalam meningkatkan kemampuan pemecahan matematis siswa.

Haryani, Amelia, \& Yulia (2014) menjelaskan bahwa hasil belajar matematika yang diajarkan menggunakan strategi pembelajaran kooperatif kombinasi STAD dan TGT lebih baik dibandingkan dengan hasil belajar matematika yang diajarkan menggunakan strategi pembelajaran konvensional. Penerapan strategi pembelajaran STAD dan TGT juga dapat meningkatkan pengetahuan siswa dalam matematika (Siswono, Hartono, Kohar, Karim, \& Lastiningsih, 2019). Sementara itu Saragih \& Napitupulu (2015) menjelaskan bahwa ada hubungan antara strategi pembelajaran yang digunakan guru dan pemikiran kreatif dengan hasil belajar matematika siswa. Murtiyasa, Rejeki, Setyaningsih, \& Merdekawati (2019) mengatakan bahwa sangat penting untuk mendisain pembelajaran matematika untuk meningkatkan level berpikir pada siswa. Oleh karena itu sangat penting memilih strategi pembelajaran yang tepat. Berdasarkan uraian-uraian tersebut, tampak belum banyak yang mengkaji keterkaitan antara strategi pembelajaran STAD dan TGT terhadap hasil belajar matematika yang ditinjau dari kreativitas siswa.
Pada prakteknya masih banyak ditemui guru yang menggunakan strategi pembelajaran langsung dengan alasan lebih praktis, tidak perlu banyak persiapan, serta menghemat waktu. Penerapan strategi pembelajaran yang tidak inovatif menyebabkan siswa merasa bosan sehingga berdampak siswa tidak tertarik dengan pembelajaran matematika dan berpengaruh terhadap hasil belajar yang diperoleh siswa. Strategi pembelajaran yang kurang baik juga tidak mampu membangkitkan proses kreatif siswa. Sementara diketahui bahwa kreativitas yang dimiliki siswa juga berpengaruh terhadap hasil belajar. Oleh karena itu perlu mempertimbangkan strategi pembelajaran yang tepat untuk membangkitkan kreativitas dan meningkatkan hasil belajar siswa. Strategi pembelajaran yang disarankan adalah strategi STAD dan TGT. Penerapan kedua strategi tersebut diharapkan dapat memberikan kesempatan kepada siswa untuk menggunakan kreativitasnya dalam proses belajar, sehingga akan berpengaruh terhadap hasil belajar. Kedua strategi pembelajaran tersebut pada gilirannya diharapkan dapat memberikan pengaruh positif terhadap hasil belajar matematika siswa.

Memperhatikan uraian tersebut, tujuan penelitian ini adalah: (1) menganalisis pengaruh strategi pembelajaran STAD dan TGT terhadap hasil belajar matematika, menganalisis pengaruh kreativitas siswa terhadap hasil belajar matematika, dan (3) mengetahui interaksi antara strategi pembelajaran dan kreativitas terhadap hasil belajar matematika.

Berdasar pada tujuan tersebut, penelitian ini mengajukan hipotesis untuk diuji, yaitu: (1) ada pengaruh strategi pembelajaran STAD dan TGT 
terhadap hasil belajar matematika, (2) ada pengaruh kreativitas siswa terhadap hasil belajar matematika, dan (3) ada interaksi antara strategi pembelajaran dan kreativitas siswa terhadap hasil belajar matematika.

\section{METODE PENELITIAN}

Jenis penelitian berdasarkan pendekatannya merupakan penelitian kuantitatif. Desain penelitian ini adalah eksperimen semu dengan jenis posttest only, nonequivalent control group design. Populasi dalam penelitian ini adalah seluruh siswa kelas VII SMP Negeri 3 Colomadu dengan jumlah 255 siswa. Teknik pengambilan sampel menggunakan cluster random sampling. Terpilih sebagai sampel penelitian kelas VII H sebagai kelas eksperimen dengan jumlah 31 siswa dan kelas VII G sebagai kelas kontrol dengan jumlah 32 siswa. Kelas eksperimen diberikan pembelajaran menggunakan strategi STAD, sedangkan kelas kontrol diberikan pembelajaran menggunakan strategi TGT.

Teknik pengumpulan data menggunakan metode tes, angket, dan dokumentasi. Metode tes digunakan untuk mendapatkan data hasil belajar siswa setelah kedua kelompok sampel diberi perlakukan pembelajaran. Metode angket digunakan untuk mendapatkan data tentang kreativitas siswa. Metode dokumentasi digunakan untuk mendapatkan data kemampuan awal siswa sebelum dilakukan perlakuan kegiatan proses pembelajaran. Data kemampuan awal berupa dokumen hasil ujian tengah semester (UTS) pada semester ganjil tahun pelajaran 2019/2020. Data kemampuan awal digunakan untuk uji keseimbangan dua kelompok sampel.

Uji validitas instrumen tes dan angket menggunakan rumus korelasi product moment. Sedangkan uji reliabilitas menggunakan rumus alpha Cronbach. Uji normalitas sebagai prasyarat analisis menggunakan uji Lilliefors dengan taraf siginifikansi $5 \%$. Sedangkan uji homoginitas kedua kelompok sampel menggunakan uji Bartlett dengan taraf siginifikansi 5\%.

Teknik analisis data menggunakan analisis varian (ANAVA) dua jalan dengan sel tak sama. Uji anava menggunakan taraf signifikansi 5\%. Uji komparasi dengan metode Scheffe' digunakan sebagai uji lanjutan untuk mengetahui efektifitas dari kedua strategi pembelajaran.

\section{HASIL DAN PEMBAHASAN}

Sebelum kedua kelas sampel diberikan perlakuan, terlebih dahulu dilakukkan uji keseimbangan untuk memastikan bahwa kelas eksperimen dan kelas kontrol mempunyai keadaan yang seimbang atau sama. Data yang digunakan untuk uji keseimbangan yaitu nilai Ujian Tengah Semester (UTS) semester ganjil siswa kelas eksperimen dan kelas kontrol tahun pelajaran 2019/2020. Berdasarkan hasil perhitungan uji keseimbangan dengan uji $\mathrm{t}$, diperoleh $t_{\text {hitung }}=0,175$ dan $t_{\text {tabel }}$ dengan taraf signifikansi $5 \%$ yaitu 1,999. Nilai $t_{\text {hitung }}<t_{\text {tabel }}$, ini berarti $\mathrm{H}_{0}$ diterima, dapat disimpulkan bahwa kelas eksperimen dan kelas kontrol memiliki kemampuan awal matematika yang seimbang sebelum perlakuan.

Uji instrumen tes dari 9 (sembilan) soal yang diujicobakan, diketahui ada 5 (lima) soal yang valid. Reliabilitas instrumen tes termasuk tinggi, hal ini ditunjukkan dengan hasil uji reliabilitas instrument tes $r_{11}=0,747$. Sementara itu untuk uji validitas instrument angket kreativitas, dari 35 item terdapat 30 item yang valid, dengan reliabilitas angket yang tinggi 
sebesar $r_{11}=0,899$. Dengan demikian Instrumen tes yang terdiri dari 5 soal yang valid dan reliabel serta instrument tes dengan 30 item yang valid dan reliabel digunakan untuk mendapatkan data hasil belajar dan kreativitas siswa.

Proses pembelajaran dilakukan sebanyak empat kali pertemuan. Pada pertemuan pertama, diajarkan materi tentang kalimat terbuka, tertutup, dan mengubah pernyataan sehari-hari kedalam kalimat matematika. Pertemuan kedua diajarkan materi tentang menentukan penyelesaian persamaan linear satu variabel dan aplikasinya. Pertemuan ketiga diajarkan tentang topik menyelesaikan pertidaksamaan linear satu variabel dan apalikasinya. Pada pertemuan terakhir, siswa dari kedua sampel diberi tes evaluasi hasil belajar matematika pada pokok bahasan persamaan dan pertidaksamaan linier satu variabel dan pengisian angket kreativitas.

Tabel 1. Hasil analisis uji normalitas.

\begin{tabular}{cccc}
\hline Sumber & $\boldsymbol{L}_{\text {hitung }}$ & $\boldsymbol{L}_{\text {tabel }}$ & Keputusan \\
\hline $\operatorname{STAD}\left(A_{1}\right)$ & 0,062 & 0,159 & Normal \\
$\operatorname{TGT}\left(A_{2}\right)$ & 0,152 & 0,157 & Normal \\
$\begin{array}{c}\text { Kreativitas } \\
\text { Tinggi }\left(B_{1}\right)\end{array}$ & 0,119 & 0,206 & Normal \\
$\begin{array}{c}\text { Kreativitas } \\
\text { Sedang } \\
\left(B_{2}\right)\end{array}$ & 0,128 & 0,171 & Normal \\
$\begin{array}{c}\text { Kreativitas } \\
\text { Rendah } \\
\left(B_{3}\right)\end{array}$ & 0,130 & 0,195 & Normal \\
\hline
\end{tabular}

Hasil uji normalitas dengan metode Lilliefors pada taraf signifikansi 5\% menunjukkan bahwa data yang diperoleh berdistribusi normal. Hasil lengkap rangkuman uji normalitas seperti tercantum pada Tabel 1 . Menurut Tabel 1 tersebut diperoleh hasil bahwa $L_{\text {hitung }}<L_{\text {tabel }}$ untuk setiap sampel, hasil ini menunjukkan bahwa sampel berasal dari populasi yang berdistribusi normal.

Selanjutnya uji homoginitas menggunakan metode Bartllet dengan taraf signifikansi 5\% menunjukkan bahwa kedua kelompok sampel berasal dari populasi yang homogin. Hasil perhitungan uji homoginitas diperoleh $\chi_{\text {hitung untuk strategi pembelajaran }}^{2}$ yaitu $\chi_{\text {hitung }}^{2}=0,692$ dan kreativitas siswa yaitu $\chi_{\text {hitung }}^{2}=4,959$, dengan $\chi_{\text {tabel }}^{2}=3,841$ untuk strategi pembelajaran dan $\chi_{\text {tabel }}^{2}=5,991$ untuk kreativitas siswa. Hasil ini menjukkan bahwa bahwa $\chi_{\text {hitung }}^{2}<\chi_{\text {tabel }}^{2}$, yang berarti sampel berasal dari populasi yang homogen.

Dari uraian tersebut menunjukkan bahwa hasil uji prasyarat analisis memberikan gambaran bahwa kedua kelompok sampel dalam keadaan seimbang, berdistribusi normal, dan homogen. Oleh karena itu dapat dilanjutkan untuk tahapan pengujian hipotesis. Uji hipotesis menggunakan ANAVA dua jalan dengan sel tak sama. Rangkuman hasil perhitungan disajikan pada Tabel 2.

Berdasarkan Tabel 2 dapat diiintepretasikan hasil dari analisis variansi dua jalan dengan sel tak sama sebagai berikut.

1) Pada baris pertama menunjukkan bahwa $F_{A}>F_{\text {tabel }}$ maka $\mathrm{H}_{0 \mathrm{~A}}$ ditolak. Artinya terdapat pengaruh strategi pembelajaran STAD dan TGT terhadap hasil belajar matematika.

2) Pada baris kedua menunjukkan bahwa $F_{B}>F_{\text {tabel }}$ maka $\mathrm{H}_{0 \mathrm{~B}}$ ditolak. Artinya terdapat pengaruh 
DOI: https://doi.org/10.24127/ajpm.v9i2.2765

kreativitas siswa terhadap hasil belajar matematika.

3) Pada baris ketiga menunjukkan bahwa $F_{A B}<F_{\text {tabel }}$ maka $\mathrm{H}_{0 \mathrm{AB}}$ diterima. Artinya tidak terdapat interaksi antara strategi pembelajaran dan kreativitas siswa terhadap hasil belajar matematika.

Tabel 2. Rangkuman hasil ANAVA.

\begin{tabular}{ccccccc}
\hline Sumber & JK & DK & RK & $\boldsymbol{F}_{\text {obs }}$ & $\boldsymbol{F}_{\text {tabel }}$ & Keputusan \\
\hline Strategi (A) & 942,126 & 1 & 942,126 & 11,412 & 4,010 & $\mathrm{H}_{0}$ Ditolak \\
Kreativitas Siswa (B) & 793,578 & 2 & 396,789 & 4,806 & 3,159 & $\mathrm{H}_{0}$ Ditolak \\
Interaksi (AB) & 101,024 & 2 & 50,512 & 0,612 & 3,159 & $\mathrm{H}_{0}$ Diterima \\
Galat & 4705,577 & 57 & 82,554 & - & - & \\
Total & 6542,306 & 62 & - & - & - & \\
\hline
\end{tabular}

Berdasarkan keputusan uji pada analisis variansi dua jalan dengan sel tak sama diperoleh bahwa $\mathrm{H}_{0 \mathrm{~A}}$ ditolak dan $\mathrm{H}_{0 \mathrm{~B}}$ ditolak. Pada penelitian ini yang dilakukkan uji lanjut komparasi ganda adalah $\mathrm{H}_{0 \mathrm{~B}}$ karena memiliki tiga katagori maka perlu dilakukan uji komparasi ganda dengan metode Scheffe'. Untuk melakukan komparasi ganda ditentukan dahulu rerata masingmasing sel dan rerata marginalnya yang hasilnya disajikan dalam Tabel 3.

Tabel 3. Rerata hasil belajar dan kreativitas siswa.

\begin{tabular}{lcccc}
\hline \multirow{2}{*}{$\begin{array}{c}\text { Strategi } \\
\text { Pembelajaran }\end{array}$} & \multicolumn{3}{c}{ Kreativitas Siswa } & Rerata Marginal \\
\cline { 2 - 4 } & Tinggi & Sedang & Rendah & \\
\hline STAD & 78,364 & 74,250 & 66,250 & 72,955 \\
TGT & 67,500 & 65,400 & 61,727 & 64,876 \\
Rerata Marginal & 72,932 & 69,825 & 63,989 & \\
\hline
\end{tabular}

Hipotesis pertama menunjukkan bahwa $\mathrm{H}_{0 \mathrm{~A}}$ ditolak, maka terdapat pengaruh strategi pembelajaran STAD dan TGT terhadap hasil belajar matematika. Rerata marginal kelompok siswa yang diberikan perlakuan strategi pembelajaran STAD yaitu 72,955, sedangkan rerata marginal kelompok siswa yang diberikan perlakuan strategi pembelajaran TGT yaitu 64,876 .
Dengan memperhatikan rerata marginalnya, dapat disimpulkan bahwa hasil belajar matematika siswa yang diberi pembelajaran menggunakan strategi pembelajaran STAD lebih baik dibandingkan dengan siswa yang diberi pembelajaran menggunakan dengan strategi TGT. Senada dengan penelitian yang dilakukkan Sepriyanti, Nofadila, Marhamah, Kustati, \& Sabri (2019) 
menunjukkan bahwa penerapan strategi STAD dan TGT efektif untuk meningkatkan hasil belajar matematika. Ada perbedaan yang signifikan dalam hasil belajar menggunakan strategi STAD dan TGT. Nilai rata-rata hasil belajar dengan strategi pembelajaran STAD yaitu 81,56 , sedangkan nilai ratarata hasil belajar dengan strategi TGT yaitu 74,94. Dengan memperhatikan rata-ratanya dapat disimpulkan bahwa STAD lebih baik daripada TGT. Rakhmawati (2015) menyimpulkan bahwa penerapan strategi pembelajaran kooperatif dengan tipe STAD dapat meningkatkan hasil belajar matematika siswa dan aktivitas belajar siswa.

Hipotesis kedua menunjukkan bahwa $\mathrm{H}_{0 \mathrm{~B}}$ ditolak, maka terdapat pengaruh kreativitas siswa terhadap hasil belajar matematika, yang artinya terdapat perbedaan hasil belajar matematika antara siswa yang memiliki kreativitas katagori tinggi, sedang, dan rendah. Senada dengan penelitian Wilda et al. (2017) juga menunjukkan bahwa terdapat pengaruh antara kreativitas dan minat belajar terhadap hasil belajar matematika. Sejalan dengan penelitian Ayuni, Mardiyana, \& Riyadi (2014) menyimpulkan bahwa ada perbedaan hasil belajar matematika siswa yang diajarkan dengan strategi TGT dan STAD berbantuan media GeoGebra pada materi program linier dan ada pengaruh antara kreativitas belajar dengan hasil belajar matematika. Hasil belajar siswa dengan kreativitas tinggi lebih baik daripada kreativitas sedang dan rendah. Pada penelitian Vahlia (2014) menyimpulkan bahwa hasil belajar matematika siswa yang memiliki kreativitas tinggi lebih baik dibandingkan kreativitas sedang maupun rendah.

Setelah dilakukan perhitungan uji komparasi ganda pada rerata antar kolom menggunakan metode Scheffe, diperoleh hasil analisis seperti ditunjukkan pada Tabel 4.

Tabel 4. Hasil Komparasi Ganda Rerata Antar Kolom.

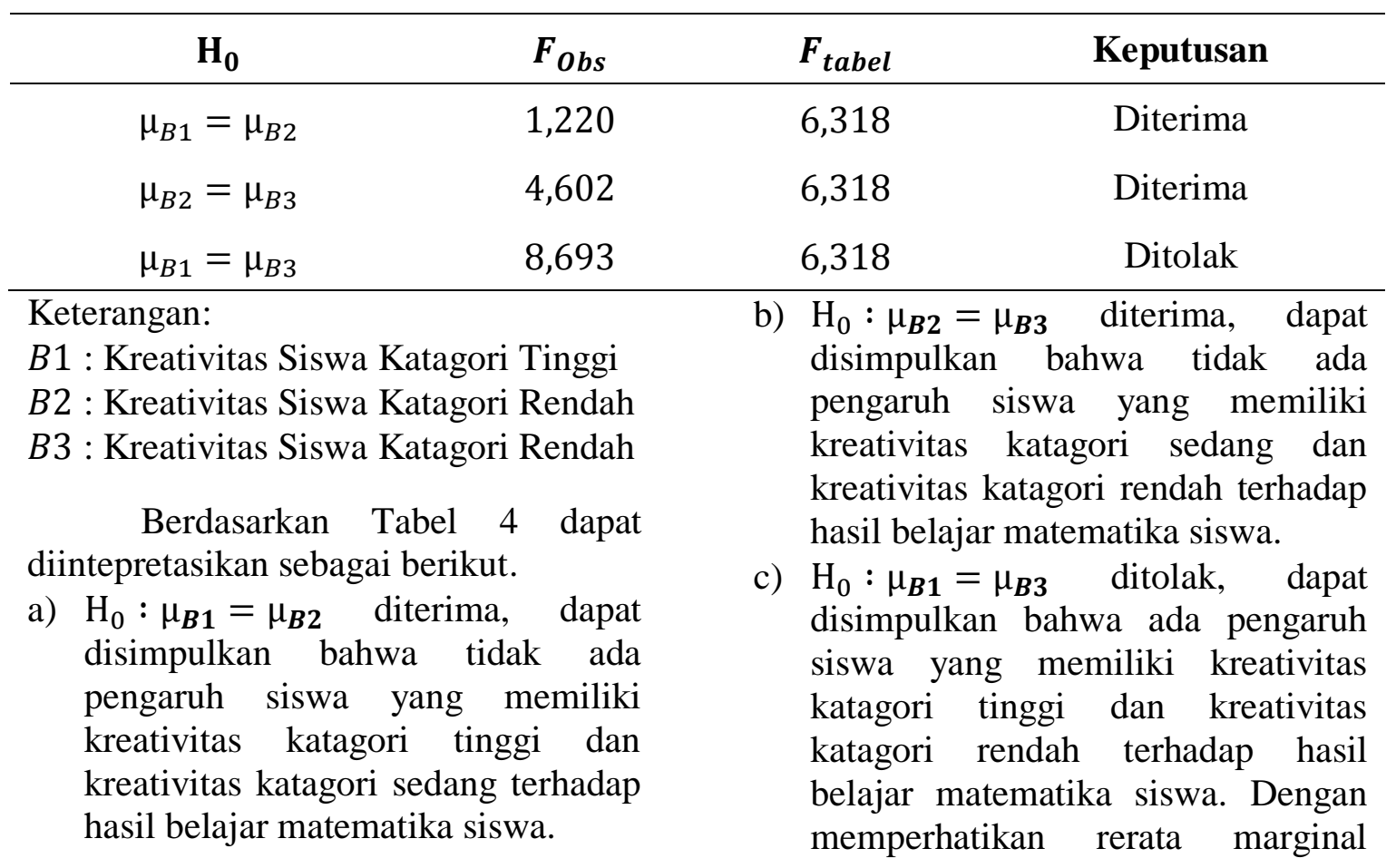


kreativitas katagori tinggi sebesar 72,932 dan kreativitas katagori rendah sebesar 63,989, dapat disimpulkan bahwa siswa yang memiliki kreativitas katagori tinggi memperoleh hasil belajar matematika yang lebih baik dibandingkan dengan siswa yang memiliki kreativitas katagori rendah.
Hipotesis ketiga menunjukkan bahwa $\mathrm{H}_{0 \mathrm{AB}}$ diterima, yang berarti tidak terdapat interaksi antara strategi pembelajaran dan kreativitas siswa terhadap hasil belajar matematika. Pada Gambar 1, secara grafis tidak adanya interaksi di antara variabel-variabel bebas dapat dilihat dari garis grafik yang tidak berpotongan.

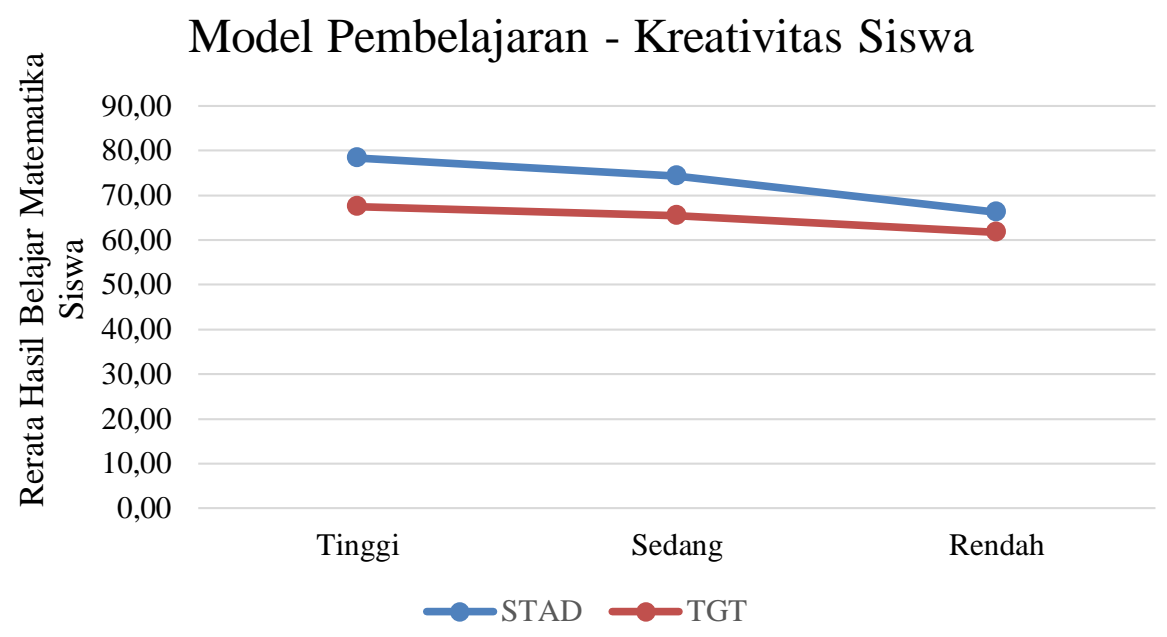

Gambar 1. Grafik pengaruh variabel bebas terhadap variabel terikat.

Hasil penelitian ini bertentangan dengan hasil penelitian Vahlia (2014) yang menyatakan bahwa terdapat interaksi model pembelajaran dan katagori kreativitas siswa terhadap prestasi belajar. Akan tetapi hasil penelitian ini sejalan dengan penelitian Ayuni et al. (2014) yang menyimpulkan bahwa tidak terdapat interaksi model pembelajaran berbantu GeoGebra dengan kreativitas siswa terhadap hasil belajar matematika materi program linier.

Pemilihan strategi pembelajaran yang tepat sangat mempengaruhi hasil belajar yang diperoleh siswa. Hasil belajar matematika siswa yang diajarkan dengan strategi STAD lebih baik daripada siswa yang diajarkan dengan strategi TGT. Hal tersebut didukung dengan sikap siswa saat pembelajaran menggunakan strategi STAD. Siswa lebih aktif dalam diskusi kelompok untuk menyelesaiakan masalah LKPD maupun ketika kuis. Selama proses pembelajaran berlangsung semua siswa berusaha menentukan penyelesaian dari permasalahan yang ada dengan diskusi kelompok sebelum bertanya kepada guru. Semua siswa aktif dalam diskusi kelompok untuk menyelesiakan masalah yang diberikan oleh guru. Selama pembelajaran, siswa terlihat bersemangat saat kerja kelompok dan tidak ada anggota kelompok yang pasif karena dengan kerja kelompok memungkinkan siswa untuk mengungkapkan ide-ide yang mereka miliki untuk menyelesaikan masalah 
yang diberikan guru. Penerapan strategi STAD juga dapat meminimalkan kompetisi antar siswa karena strategi ini meningkatkan kerja sama antar anggota dalam sebuah kelompok untuk mendapatkan point yang tertinggi dalam pembelajaran.

Oleh karena itu strategi STAD dapat diterapkan guru dalam proses pembelajaran sebagai upaya untuk meningkatkan hasil belajar siswa. Hasil dari penelitian ini dapat dijadikan referensi dalam memilih strategi pembelajaran yang tepat agar hasil belajar matematika meningkat.

\section{KESIMPULAN DAN SARAN}

Berdasarkan hasil penelitian dan pembahasan dapat disimpulkan bahwa terdapat pengaruh strategi STAD dan TGT terhadap hasil belajar matematika. Hasil belajar matematika siswa yang diberi pembelajaran menggunakan strategi pembelajaran STAD lebih baik dibandingkan dengan siswa yang diberi pembelajaran menggunakan strategi pembelajaran TGT. Terdapat pengaruh kreativitas siswa terhadap hasil belajar matematika. Hasil belajar matematika siswa yang memiliki kreativitas tinggi lebih baik daripada siswa yang memiliki kreativitas rendah. Tidak ada interaksi antara strategi pembelajaran STAD dan TGT dengan kreativitas siswa terhadap hasil belajar matematika. Adapun saran yang dapat diberikan peneliti untuk penelitian selanjutnya yang relevan yaitu pembelajaran daring dengan strategi pembelajaraan kooperatif dimasa pandemic covid-19.

\section{DAFTAR PUSTAKA}

Alabekee, E. C., Samuel, A., \& Osaaat, S. D. (2019). EFFECT OF COOPERATIVE LEARNING STRATEGY ON STUDENTS LEARNING EXPERIENCE AND
ACHIEVEMENTS IN

MATHEMATICS. Journal of

Chemical Information and

Modeling, 53(9), 1689-1699.

https://doi.org/10.1017/CBO97811

07415324.004

Ayuni, P., Mardiyana, \& Riyadi. (2014). Eksperimentasi Model Pembelajaran Kooperatif Tipe Teams Games Tournament Dan Student Teams Achievement Division Berbantuan Media Geogebra Pada Materi Program Linear Ditinjau Dari Kreativitas Belajar Siswa Kelas Xii Ipa Sma Negeri Se-Kabupaten Kudus. Jurnal Elektronik Pembelajaran Matematika, 2(3), 270-280.

Haryani, D., Amelia, F., \& Yulia, P. (2014). Pengaruh Model Pembelajaran Kooperatif Kombinasi Stad Dan Tgt Terhadap Hasil Belajar Matematika Siswa Kelas Viii Di Mts Usb Sagulung Batam. Pythagoras, 3(2), 40-45.

Jahring, Armiana, \& Nasrum, A. (2017). Comparative Study Of Mathematics Learning Students Outcomes Taught By Cooperative Learning Model Teams Games Tournament Type ( Tgt ) And Talking Stick Type ( Ts ). Journal of Mathematics Education, 2(20), 59-65.

Ling, W. N., Ghazali, M. I., \& Raman, A. (2016). The Effectiveness of Student Teams Achievement Division (STAD) Cooperative Learning on Mathematics Comprehension Among School Students. Internasional Journal of Advanced Research and Development, 2(4), 30-35.

Murtiyasa, B., Rejeki, S., Setyaningsih, R., \& Merdekawati, A. (2019). Students' Thinking in Solving Geometric Problems Based on 
PISA Levels. Journal of Physics: Conference Series, 1320(1), 6-12. https://doi.org/10.1088/17426596/1320/1/012068

Nurafifaeni, A., Triyanto, \& Chrisnawati, H. E. (2018). EKSPERIMENTASI MODEL PEMBELAJARAN KOOPERATIF TIPE STUDENT TEAMS ACHIEVEMENT DIVISION (STAD) DENGAN MIND MAPPING PADA MATERI FUNGSI DITINJAU DARI KREATIVITAS SISWA KELAS VIII SMP NEGERI 13 SURAKARTA TAHUN PELAJARAN 2017/ 2018. (3), 179-186.

Puspitasari, D., Muliawanti, S., Gunawan, \& Sairan. (2019). Analisis Kemampuan Pemecahan Masalah Matematis Siswa Menggunakan Model Pembelajaran Team Games Tournament Sma Muhammadiyah 1 Purwokerto. AKSIOMA: Jurnal Program Studi Pendidikan Matematika, 8(1), 83-90. https://doi.org/10.24127/ajpm.v8i1. 1731

Rakhmawati, R. (2015). Upaya meningkatkan aktivitas dan prestasi belajar matematika siswa kelas XI IPA 1 SMAN 1 Amuntai tahun pelajaran 2013/2014 melalui pembelajaran kooperatif tipe STAD. Math Didactic: Jurnal Pendidikan Matematika, 1(2), 116-123.

https://doi.org/10.33654/math.v1i2. 12

Rattanatumma, T. (2016). Assessing the Effectiveness of STAD Model and Problem Based Learning in Mathematics Learning Achievement and Problem Solving Ability. Journal of Education and Practice, 7(12), 194-199.
Salam, A., Hossain, A., \& Rahman, S. (2015). Teams Games Tournaments ( TGT ). Cooperative Technique for Learning Mathematics in Secondary Schools in Bangladesh. Malaysian Online Journal of Educational Technology, 3(3), 271-287. https://doi.org/10.4471/redimat.20 15.1519

Saragih, S., \& Napitupulu, E. (2015). Developing student-centered learning model to improve high order mathematical thinking ability. International Education Studies, 8(6), 104-112. https://doi.org/10.5539/ies.v8n6p1 04

Sepriyanti, N., Nofadila, Marhamah, Kustati, M., \& Sabri, A. (2019). Utilization of students team achievement division and team game tournament: Effective ways to increase students' mathematics ability. International Journal of Scientific and Technology Research, 8(4), 80-85.

Siswono, T. Y. E., Hartono, S., Kohar, A. W., Karim, K., \& Lastiningsih, N. (2019). How do prospective teachers manage students' learning of mathematics? TEM Journal, 8(2), 677-685. https://doi.org/10.18421/TEM8249

Vahlia, I. (2014). Ekperimentasi Model Pembelajaran Discovery dan Group Investigation Terhadap Prestasi Belajar Matematika Ditinjau dari Kreativitas Siswa. AKSIOMA Journal of Mathematics Education, 3(2), 43-54. https://doi.org/10.24127/ajpm.v3i2. 11

Veloo, A., Md-Ali, R., \& Chairany, S. (2016). Using cooperative teamsgame-tournament in 11 religious 
DOI: https://doi.org/10.24127/ajpm.v9i2.2765

school to improve mathematics understanding and communication. Malaysian Journal of Learning and Instruction, 13(2), 97-123. https://doi.org/10.32890/mjli2016. 13.2.4

Wilda, Salwah, \& Ekawati, S. (2017). Pengaruh kreativitas dan minat belajar terhadap hasil belajar matematika siswa. Pedagogy: Jurnal Pendidikan Matematika, 2(1), 134-144. 